\title{
Understanding of Human Papilloma Virus Vaccine Receipt among Adolescents in Trinidad and Tobago
}

\author{
NN Modeste ${ }^{1}$, D-A Sealy ${ }^{2}$, P Dyett ${ }^{3}$
}

\begin{abstract}
Objective: To understand the barriers or factors that may hinder receipt of the human papilloma virus (HPV) among adolescent girls, 14-18 years old, and evaluate the awareness level about HPV and the HPV vaccine acceptance.

Methods: A questionnaire consisting of two parts, demographic and family history of cervical cancer, and a cluster of questions about HPV, was distributed to 651 female adolescents in 17 secondary schools in Trinidad and Tobago to determine knowledge, attitude, and awareness levels pertaining to HPV and acceptance of the HPV vaccine. Chi-square tests and logistic regressions were used.

Results: Of the 651 students completing questionnaires, the majority (61\%) were in the 15-16 age group; and $76 \%$ were either of African descent or multi-racial. There were significant associations between a family member having a diagnosis of cervical cancer and knowledge that cervical cancer is caused by the HPV virus, that the virus is spread sexually, and the likelihood of getting cervical cancer in the future $(p=<0.05)$. However, the majority (63\%) did not know that cervical cancer is caused by the HPV virus or that the virus was spread sexually. Conclusion: Lack of knowledge of the HPV vaccine was seen among adolescents from each school. There is need for education on cervical cancer and its causes, and the HPV virus.
\end{abstract}

Keywords: Adolescents, HPV vaccine receipt, Trinidad and Tobago

\section{Comprensión del Recibo de la Vacuna Contra el VPH entre los Adolescentes en Trinidad y Tobago \\ NN Modeste ${ }^{1}$, D-A Sealy², P Dyett ${ }^{3}$}

\begin{abstract}
RESUMEN
Objetivo: Entender las barreras o factores que pueden obstaculizar la recepción del virus del papiloma humano (VPH) entre las adolescentes, de 14-18 años, y evaluar el nivel de concientización sobre el VPH y la aceptación de la vacuna contra el VPH.

Métodos: Un cuestionario de dos partes -antecedentes demográficos e historia familiar de cáncer cervicouterino--, y un grupo de preguntas sobre el VPH, fueron distribuidos entre 651 adolescentes femeninas en 17 escuelas secundarias de Trinidad y Tobago para determinar los niveles de conocimiento, actitud y concientización relacionados con el VPH y la aceptación de la vacuna contra el VPH. Se utilizaron pruebas de Chi-cuadrada y regresiones logísticas.
\end{abstract}

From: ${ }^{1}$ University, School of Public Health, Center for Nutrition, Healthy Lifestyle, and Disease Prevention, Loma Linda, California 92350, USA, ${ }^{2}$ Diadrey-Anne Sealy, University of the Southern Caribbean, Trinidad and Tobago, ${ }^{3}$ Patricia Dyett, University of the West Indies, St Augustine, Trinidad.
Correspondence: Professor NN Modeste, Loma Linda University, School of Public Health, Center for Nutrition, Healthy Lifestyle, and Disease Prevention, Loma Linda, California 92350, USA.

E-mail: nmodeste@1lu.edu 
Resultados: De las 651 estudiantes que respondieron los cuestionarios, la mayoría (61\%) estaban en el grupo de edad de 15-16 años; y el 76\% eran de ascendencia africana o multirracial. Hubo asociaciones significativas entre un miembro de la familia con diagnóstico de cáncer cervical y el conocimiento de que el cáncer cervical es causado por el virus del VPH, que el virus se propaga sexualmente, y que existe la probabilidad de contraer cáncer cervical en el futuro $(\mathrm{p}=<0.05)$. Sin embargo, la mayoría (63\%) no sabía que ese tipo de cáncer es causado por el virus VPH, ni que el virus se propaga sexualmente.

Conclusión: Se observó falta de conocimiento de la vacuna contra el VPH entre las adolescentes de cada escuela. Hay necesidad de educación sobre el cáncer cervical y sus causas, y el virus del VPH.

Palabras clave: Adolescentes, recibo de la vacuna contra el VPH, Trinidad y Tobago

\section{West Indian Med J 2019; 68 (2): 155}

\section{INTRODUCTION}

Cervical cancer is a major public health problem in the developing world, including Latin America and the Caribbean [LAC] (1-3), and the second most common cancer (after breast cancer) among women in LAC. Cervical cancer affects relatively young women while still involved in their careers, and caring for family, resulting in more lives lost than many other cancers. The LAC region accounts for $14.6 \%$ of the worldwide cervical cancer cases, and $11.95 \%$ of cervical cancer deaths (4). Recent estimates indicate that if current incidence rates continue, and current screening efforts kept at present levels of effectiveness, by 2025 developing countries will face an increase of $75 \%$ in the burden of cervical cancer $(1,5)$. Cervical cancer rates in Latin America and the Caribbean countries are high compared to other regions of the world, except Africa (3).

Pap smear screening was introduced in LAC in the 1960s and although attempts to implement national programmes have been pursued, the successful reduction of cervical cancer incidence and mortality that has been achieved in other developed countries has not been replicated in LAC (3). Failure to reduce the burden of cervical cancer, may be due to socio-economic factors, lack of organized screening, limitations of techniques, poor quality control, low population coverage, and insufficient monitoring, treatment and follow-up of women with abnormal cytology results (5).

The cervical cancer incidence rate in Trinidad and Tobago is about two times higher than the worldwide rate (6). Trinidad and Tobago ranks number 18 in the region with an age standardized incidence rate of 27.1 per 100 000, when compared to Puerto Rico with a rate of 8.8 per 100000 (1). Mortality rates are much higher in the Caribbean, including Trinidad and Tobago (10.7 per 100 000), than in North America which has a rate of 2.3 per 100000 (1).

With the advent of screening programmes, the incidence of abnormal cervical cytology has been rising among women of reproductive age, and conservative methods to treat cervical intraepithelial neoplasia (CIN) and microinvasive cervical cancers are often used on young women. The incidence of CIN requiring treatment tends to peak around the age of 30, and the possible effect on future childbearing is of great importance (7). Recent research on conization (tissue excision) to treat CIN has been linked to the risk of preterm births. While it is still controversial, conization of the cervix for treatment of CIN is known to be related to adverse pregnancy outcomes including preterm delivery, low birth weight infants, incompetent cervix, and cervical stenosis $(8,9)$. It is expected that the HPV vaccine would reduce the need for conization therefore improving perinatal mortality and other adverse pregnancy outcomes in the long-term.

Human papillomavirus vaccination may reduce cervical cancer burden through primary prevention of HPV infection. Two brands of HPV vaccines are available, a bivalent (Ceravix) and a quadrivalent vaccine that is also effective against non-oncogenic types, HPV 16 and 11, which cause most genital warts (10). Human papilloma virus infections are usually acquired soon after sexual debut; therefore the vaccine is most effective if administered before onset of sexual activity. Either HPV vaccine is routinely recommended for 11-12-year-old girls and 13-26-year-old females (10).

Surveys conducted across the region have shown median age at first sexual intercourse to be in the early 
to mid-teens, or in the case of some studies with boys, at even younger ages. Data from the largest Englishspeaking Caribbean Youth Health Survey, conducted among 15695 youths, aged 10-18, attending school, in nine countries, revealed $34 \%$ responded in the affirmative to ever having sexual intercourse. Over half of the sexually active boys, and a quarter of the sexually active girls said that their age at first intercourse was 10 years old or younger (11). Additionally, the first sexual intercourse of $47.6 \%$ girls and $31.9 \%$ of boys who were sexually active was forced or coerced (12). The Pan American Health Organization adolescent survey revealed that $38 \%$ of young people said their first intercourse was forced. In Tobago, $7 \%$ of first sexual encounters by males and $6 \%$ of those by females were reported to be incestuous (13). These victims usually have little choice over whether birth control would be used during the encounter and they may often contract a sexually transmitted infection (STI). Reports of other risky sexual behaviours include young females being sexually initiated by significantly older males $(13,14)$; and transactional sex with older men for school fees, money and clothing (12).

Research conducted in the United States of America (USA) to determine adolescents' understanding and acceptance of the HPV vaccine found that only $4 \%$ of adolescents in the study believed that they were at risk for HPV infection, but $52 \%$ were willing to be vaccinated. There was a general lack of awareness of HPV among the students in the study. Yet HPV is the most common sexually transmitted virus in the USA with at least $50 \%$ of all sexually active persons having acquired it in their lifetime (15). Because of the high incidence of cervical cancer in the LAC region, including Trinidad and Tobago, we saw a need for similar investigations into the knowledge, understanding and acceptance of the HPV vaccine in relation to cervical cancer in Trinidad and Tobago. To the best of our knowledge, no other study has specifically investigated these variables among adolescents in the rigion.

\section{METHODS}

Recruitment for this study was done through secondary schools in Trinidad and Tobago. The principals of the selected schools were contacted and the purpose of the study explained. Information on the purpose of the study and consent forms were sent to the parents by the teachers. Female adolescents meeting the age criteria (14-18 years), and who had returned their signed consent forms, were invited to participate. Schools were only included if the principals agreed for their school to participate.

\section{Data Collection}

The sample goal was 1300 students and approximately 1600 consent forms were sent to parents; but only 651 female adolescents participated. Questionnaires were administered to approximately 16 schools during a class period by the researchers, or other assigned personnel. Data collection lasted for 4.5 months from mid-March until June, 2014. The questionnaire consisted of two parts; the first section elicited the adolescent's demographic information, including parents' education and family history. The second section was broken into clusters of questions on knowledge, beliefs, and attitudes about cervical cancer, the HPV vaccine and the spread of the HPV virus. Two questions were included on intention or how willing they were to accept the vaccine in the future. Some questions elicited responses by using Likert type scales, for example, a scale of 1-5 ( 1 = strongly disagree to $5=$ strongly agree), while others were yes/no responses. The question on willingness to accept the vaccine was measured on a scale of 1-10. Participants took 10-15 minutes to complete the questionnaire. Every effort was made to ensure that students did not identify themselves on the questionnaire. Any identifying information was deidentified prior to data entry.

\section{Data Analysis}

Data was entered into the Statistical Packages for the Social Sciences (SPSS) version 20. The data was cleaned and descriptive statistics were run on demographics and all categorical information. Statistical Analysis System (SAS) version 9.4 was also used to conduct logistic regression analyses on several variables for associations. Statistical tests used throughout the analysis to examine the majority of associations relevant to the questions were Chi-square and Kendal Tau; binary logistic regression when the outcome (dependent variable) was nominal and dichotomous; multinomial logistic regression when the nominal outcome had more than two levels and ordinal logistic regression when the outcome was ordinal.

\section{RESULTS}

Table 1 outlines the students' demographic characteristics. There were a total of 651 female students, aged 14-18. Of these, the majority (61\%) were $15-16$ years old, $76 \%$ were of African descent or multi-racial. In terms of religion, most $(71 \%)$ were Christians, with Pentecostals, SDAs and Catholics being the highest denominations. The data showed that $48 \%$ of mothers and fathers completed high school, while $25 \%$ of mothers and $22 \%$ of fathers completed college. 
Participants were asked where they generally go for healthcare and were given a list of facilities, from which to select more than one; $42 \%$ checked doctor's office and $29 \%$ checked community centre. Only $8 \%$ indicated that they did not get healthcare. There was no association between demographics and type of health care facility attended, but the 15-16 year-olds were more likely to go to a doctor's office for healthcare. They were also asked if they see a paediatrician and the majority $(50 \%)$ said no. Eighty-three per cent had never seen a gynaecologist.

Logistic regression analysis showed a significant difference between Hindu and Pentecostal Religions in the odds of being willing to accept the vaccination (OR $0.469 ; 95 \%$ CI $[0.257,0.855])$, with Hindus being 53\% less willing to be vaccinated for HPV. The 15 and 16 year-olds $(32 \%)$ and $(30 \%)$, respectively showed more willingness to accept the vaccine than any other age group; and $45 \%$ of African descent and 33\% multi-racial students were more willing to accept the vaccine. It was also noted, though not significantly, that girls whose parents had a high school education were more willing to accept the HPV vaccine.

Table 1: Adolescent demographics

\begin{tabular}{|c|c|}
\hline Variable & $\begin{array}{r}\text { Total } \\
\text { n (\%) } \\
\end{array}$ \\
\hline \# of Adolescents & 651 \\
\hline \multicolumn{2}{|l|}{ Gender } \\
\hline Female & $651(100)$ \\
\hline \multicolumn{2}{|l|}{ Age (years) } \\
\hline 14 & $152(23.46)$ \\
\hline 15 & $201(31.02)$ \\
\hline 16 & $192(29.63)$ \\
\hline 17 & $73(11.27)$ \\
\hline 18 & $30(4.63)$ \\
\hline \multicolumn{2}{|l|}{ Race } \\
\hline African Descent & $276(43.33)$ \\
\hline Indian & $114(17.90)$ \\
\hline Multi-racial & $208(32.65)$ \\
\hline Other & $39(6.12)$ \\
\hline \multicolumn{2}{|l|}{ Religion } \\
\hline Catholic & $118(18.27)$ \\
\hline Hindu & $64(9.91)$ \\
\hline SDA & $129(19.97)$ \\
\hline Anglican & $28(4.33)$ \\
\hline Jehovah's Witness & $17(2.63)$ \\
\hline No Religion & $24(3.72)$ \\
\hline Muslim & $17(2.63)$ \\
\hline Pentecostal & $167(25.85)$ \\
\hline Other & $82(12.69)$ \\
\hline
\end{tabular}

In examining knowledge questions, Chi-square test was used to explore whether age was associated with having heard of Pap screening. Girls, 15 and 16 years old, were more likely to say in the affirmative that they heard of Pap testing for cervical cancer.

There was a significant association between a family member having a diagnosis of cervical cancer and knowledge that cervical cancer is caused by the HPV virus, that HPV virus is spread sexually, and that there was a likelihood of getting cervical cancer in the future, or in the next few years, $p<0.05$. However, there was no significant association between family diagnosis of cervical cancer and knowledge that a Pap test can help find cancer in its early stages of development.

The impact of family history was assessed in reference to knowledge of cervical cancer and HPV. When asked if anyone in their family was diagnosed with cervical cancer, $50 \%$ said no, but $40 \%$ were unsure; only $10 \%$ had a family member diagnosed with cervical cancer. A little over 53\% had heard about the HPV virus and $70 \%$ heard about the HPV vaccine, 94\% also heard about STIs, but the majority (58\%) never heard of the Pap test, and an overwhelming $72 \%$ did not know why women received Pap screening. As to whether an older or younger sibling had received the vaccine, $69 \%$ and $78 \%$ said no for older and younger siblings, respectively. They were asked if they had received the HPV vaccine and the majority $(80 \%)$ said no; only $8 \%$ indicated that they had received the HPV vaccine, and of these, only $50 \%$ knew that the virus was spread through sexual contact. Chi-square tests showed significant evidence $(p<0.05)$ of an association between those with an older sibling who had the HPV vaccine and knowledge that cervical cancer is caused by the HPV virus.

The knowledge questions were recoded to strongly agree or agree, strongly disagree or disagree, and no opinion, since a large number seemed to have no opinion. Table 2 presents HPV and cervical cancer knowledge, showing more incorrect answers. The majority (63\%) did not know that cervical cancer is caused by the HPV virus; $56 \%$ did not know that the HPV virus is spread sexually. However, when adjusting for age, the 17 and 18 year-olds were more knowledgeable when compared to 14,15 and 16 year-olds.

In terms of beliefs about cervical cancer and HPV virus, $56 \%$ believed that it was very or moderately possible to reduce their risks of developing cervical cancer, $25 \%$ believed it was a little possible and $18 \%$ believed that it was not possible. Participants were asked if their doctor ever told them that they should get the HPV 
vaccine and $77 \%$ said no. They were to indicate if they believed the HPV vaccine would make them sick, and most $(53 \%)$ were unsure if the vaccine would get them sick. However, $16 \%$ believed that the vaccine would get them sick; $46 \%$ said they would take the vaccine if it were offered to them; $35 \%$ were unsure and $19 \%$ said they would refuse taking the vaccine.

\section{DISCUSSION}

This is the first study, to our knowledge, that has explored the barriers to the HPV vaccine in Trinidad and Tobago and the knowledge of adolescents about the HPV virus. Previous research has shown that a physician's recommendation is a significant factor in the receipt of the vaccine (16). Consequently, providers may be a major cause of the low vaccination rate (17). In addition, many young girls do not routinely see paediatricians as this is not a common practice in Trinidad and Tobago and they may be too young to begin seeing a gynaecologist.

Religion has a major influence on the culture of Trinidad and Tobago and most of LAC. This was evident in the decisions of many denominational schools to not distribute the vaccines in their schools. Any new

Table 2: Human papillomavirus and cervical cancer knowledge

\begin{tabular}{lr}
\hline Variable & $\begin{array}{c}\text { Total } \\
\mathbf{n}(\%)\end{array}$ \\
\hline Have you heard of the HPV vaccine? & $345(53.41)$ \\
$\quad$ Yes & $301(46.59)$ \\
$\quad$ No & \\
Have you heard of cervical cancer? & $451(69.60)$ \\
$\quad$ Yes & $197(30.40)$ \\
$\quad$ No & \\
Have you heard of STDS/STIs? & $613(94.31)$ \\
$\quad$ Yes & $37(5.69)$ \\
$\quad$ No & \\
Have you heard of Pap testing? & $270(41.80)$ \\
$\quad$ Yes & $376(58.20)$ \\
$\quad$ No & $181(28.02)$ \\
Do you understand and the goal of Pap screening? & $465(71.98)$ \\
$\quad$ Yes & \\
$\quad$ No & $196(30.77)$ \\
Cervical cancer is caused by the HPV virus. & $441(63.23)$ \\
$\quad$ Yes & \\
No & $281(43.84)$ \\
The HPV virus is spread sexually. & $360(56.16)$ \\
$\quad$ Yes & \\
$\quad$ No & \\
A Pap test can help you find cervical cancer when it & \\
is just getting started. & \\
$\quad$ Nes & \\
\hline & \\
\hline &
\end{tabular}

education campaign to distribute the vaccine should target and include religious leaders as gatekeepers in their communities. Paediatricians in the USA have also indicated that parental, religious and cultural beliefs may affect the acceptance of the HPV vaccine, and that Christians and Muslims may see accepting the vaccine as condoning the sexual behaviour of their children (18). Recommending the vaccine to prevent cervical cancer may be more appealing $(17,19)$. In our study, several of the religious-based schools did not allow the survey to be conducted in their schools. The major religious groups that participated in the study were Pentecostals, Seventh-day Adventists and Catholics.

Non-traditional settings, such as churches, have been used to increase vaccination against influenza in the USA (20). While churches would willingly engage in many health promotion campaigns, it is unclear whether Caribbean churches would readily promote a vaccine that is designed to prevent the spread of an STI that may lead to cancer. This can be explored in future vaccination campaigns. Theatrical health education can be used as a mechanism to educate adolescents about the vaccine and its spread. Limitations of the study include a small sample and the lack of generalizability to other populations.

\section{ACKNOWLEDGEMENTS}

The researchers would like to acknowledge the support of the Tobago House of Assembly, Roxborough Secondary School, The San Fernando General Hospital, Toco Composite School, The Point Fortin Borough Corporation and the Trinidad and Tobago Cancer Society. These organizations allowed us to use their facilities to conduct our focus groups. We would also like to acknowledge the support of many secondary school principals who allowed us to conduct our survey using their student populations. The research was supported by the Caribbean Health Research Council (CHRC/ CARPHA). The authors declare no potential conflicts of interest with respect to the research, authorship, and/or publication of this research.

\section{AUTHORS' NOTE}

Approval for this study was received from the Loma Linda University Institutional Review Board, the Trinidad and Tobago Ministry of Education, The Division of Health and Social Services, Tobago House of Assembly, and the Trinidad and Tobago Ministry of Health. There was verbal assent and written, informed consent, and no identifying information was used. 


\section{REFERENCES}

1. Almonte M, Albero G, Carcam C, Garcia PJ, Perez G. Risk factors for human papillomavirus exposure and co-factors for cervical cancer in Latin America and the Caribbean. Vaccine 2008; 26 (Suppl 11): L16-L36.

2. Muñoz N, Franco EL, Herrero R, Andrus JK, de Quadros C, Goldie SJ et al. Recommendations for cervical cancer prevention in Latin America and the Caribbean. Vaccine 2008; 26 (Suppl 11): L96-L107.

3. Murillo R, Almonte M, Pereira A, Ferrer E, Gamboa OA, Jerónimo $\mathrm{J}$ et al. Cervical cancer screening programs in Latin America and the Caribbean. Vaccine; 2008; 26 (Suppl 11): L37-L48.

4. Parkin MD, Almonte M, Bruni L, Clifford G, Curado M, Pineros M. Burden and trends of type- specific human papillomavirus infections and related diseases in the Latin America and Caribbean region. Vaccine 2008; 26 (Suppl 11): L1-L15.

5. Villa LL. Cervical cancer in Latin America and the Caribbean: the problem and the way to the solution. Cancer Epidemiology, Biomarkers Prev 2012; 21: 1409-13.

6. Ragin CR, Wheeler VW, Wilson JB, Bunker CH, Gollin SM, Patrick $\mathrm{AL}$ et al. Distinct distribution of HPV types among cancer-free AfroCaribbean women from Tobago. Biomarkers 2007; 12: 510-22.

7. Arbyn M, Kyrgiou M, Simoens C, Raifu AO, Koliopoulos G, MartinHirsch $\mathrm{P}$ et al. Perinatal mortality and other severe adversepregnancy outcomes associated with treatment of cervical intraepithelial neoplesia: meta-analysis. BMJ 2008; 337: a1284, doi: 10.1136.

8. Kyrgiou M, Koliopoulos G, Martin-Hirsch P, Arbyn M, Prendiville W, Paraskevaidis E. Obstetric outcomes after conservative treatment for intraepithelial or early invasive cervical lesions: systematic review and meta analysis. Lancet 2006; 367: 489-98.

9. Nam KH, Kwon JY, Park YW. Pregnancy outcome after cervical conization: risk factors for preterm delivery and the efficacy of prophylactic cerclage. J Gynecol Oncol 2010; 21: 225-9. Doi:10.3802/ jgo.2010.21.4.225.

10. Centers for Disease Control and Prevention (Producer). HPV vaccines, 2011. Available from: http://www.cdc.gov/hpv/vaccine.html.
11. Halcon L, Blum RW, Beuhring $\mathrm{T}$, Pate E, Campbell-Forrester S, Vename A. Adolescent health in the Caribbean: a regional portrait. Am J Public Health 2003; 93: 1851-57.

12. Roberts D, Reddock R, Douglas D, Reid S. Sex, power, and taboo: gender and HIV in the Caribbean and beyond. Kingston, Jamaica: Ian Randle Publishers; 2009.

13. Allen CF. Gender and the transmission of HIV in the Caribbean. Paper presented at the Society for Caribbean Studies Annual Conference Papers 2002. Available from: http://www.caribbeanstudies.org.uk/ papers/2002/olv3p7.PDF.

14. Bombereau G, Allen CF. Social and cultural factors driving the HIV epidemic in the Caribbean: a literature review: CHRC 2008.

15. Blumenthal J, Frey MK, Worley MJ, Tachabo NE, Soren K, Slomovitz BM. Adolescent understanding and acceptance of the HPV vaccination in the underserved population of New York. J Oncol 2012; 904034. Doi:10.1155/2012/904034.

16. Hirsch L. Why parents choose (or refuse) HPV vaccination. Consultant 2012; 52: 68.

17. Perkins RB, Clark JA. Providers' perceptions of parental concerns about HPV vaccination. J Health Care Poor Underserved 2013; 24: 828-39.

18. Tissot AM, Zimet GD, Rosenthal SL, Bernstein DI, Wetzel C, Khan JA. Effective strategies for HPV vaccine delivery: the views of pediatricians. J Adolesc Health 2007; 41: 119-25.

19. Wong LP. Physicians' experiences with HPV vaccine delivery: evidence from developing county with multiethnic populations. Vaccine 2009; 27: $1622-27$.

20. Vlahov D, Coady MH, Ompad DC, Galea S. Strategies for improving influenza immunization rates among hard-to-reach populations. J Urban Health 2007; 84: 615-31.

(c) West Indian Medical Journal 2019.

This is an article published in open access under a Creative Commons Attribution International licence (CC BY). For more information, please visit https://creativecommons.org/licenses/by/4.0/deed.en_US. 